\title{
Low-cost multi-stage filtration enhanced by coagulation-flocculation in upflow gravel filtration
}

\author{
L. D. Sánchez ${ }^{1}$, L. M. Marin ${ }^{1}$, J. T. Visscher ${ }^{2}$, and L. C. Rietveld ${ }^{3}$ \\ ${ }^{1}$ Universidad del Valle, Facultad de Ingeniería, Instituto Cinara, Cali, Colombia \\ ${ }^{2}$ JTF-Rotterdam BV, Rotterdam, The Netherlands \\ ${ }^{3}$ Delft University of Technology, P.O. Box 5084, 2600 GA Delft, The Netherlands \\ Correspondence to: L. D. Sánchez (luis.sanchez@ correounivalle.edu.co)
}

Received: 18 January 2012 - Published in Drink. Water Eng. Sci. Discuss.: 29 June 2012

Revised: 11 November 2012 - Accepted: 30 November 2012 - Published: 7 December 2012

\begin{abstract}
This paper assesses the operational and design aspects of coagulation and flocculation in upflow gravel filters (CF-UGF) in a multi-stage filtration (MSF) plant. This study shows that CF-UGF units improve the performance of MSF considerably, when the system operates with turbidity above 30 NTU. It strongly reduces the load of particulate material before the water enters in the slow sand filters (SSF) and therewith avoids short filter runs and prevents early interruption in SSF operations. The removal efficiency of turbidity in the CF-UGF with coagulant was between 85 and $96 \%$, whereas the average efficiency without coagulant dosing was $46 \%$ (range: $21-76 \%$ ). Operating with coagulant also improves the removal efficiency for total coliforms, E-coli and HPC. No reduction was observed in the microbial activity of the SSF, no obstruction of the SSF bed was demonstrated and SSF runs were maintained between 50 and 70 days for a maximum head loss of $0.70 \mathrm{~m}$. The most important advantage is the flexibility of the system to operate with and without coagulant according to the influent turbidity. It was only necessary for $20 \%$ of the time to operate with the coagulant. The CF-UGF unit represented $7 \%$ of total construction costs and the O\&M cost for the use of coagulant represented only $0.3 \%$.
\end{abstract}

\section{Introduction}

Water quality and quantity from surface sources are changing due to the deterioration of watersheds caused by deforestation, erosion, and the discharge of untreated wastewater (e.g., in Colombia only $3.1 \%$ of the total volume of wastewater produced is treated, CGR, 2009). These changes are intensified by the global climate change causing longer dry periods on the one hand and more intense rainfall on the other (Bates et al., 2008). The two most serious problems concern the peaks in turbidity level and high E-coli concentrations of long duration. These changes are affecting the existing water treatment plants, causing higher operation and maintenance $(\mathrm{O} \& \mathrm{M})$ requirements and even interruptions in their operation (Bates et al., 2008). These growing water quality problems are not unique for Colombia but imply a significant challenge in the Andean region, because surface water is the main source in the water supply systems. In Colombia about
$80 \%$ of the water supply systems are based on surface water supply (Ministerio de Desarrollo, 1998). The problems particularly affect water supply systems in rural areas and small towns, many of which even lack adequate water treatment.

Multi-Stage Filtration (MSF) is one of the more promising and reliable water treatment options for small communities. This technology uses a combination of gravel filtration (GF) in combination with slow sand filtration (SSF). Upflow gravel filtration (UGF) is the most common pre-treatment system used for MSF in Colombia (Sánchez et al., 2006a). In UGF the water passes through the gravel bed from bottom to top. During this passage impurities are retained in the filter. Upflow filtration has the advantage that the heavier particles are removed first at the bottom of the filter. Burganos et al. (1994) have reported that upflow units have an increased collection efficiency at small and medium pore inclination angles. This concept is interesting for the theoretical analysis 
of particle motion and deposition, but complex to manage in practice. When the time comes to clean the filters, the accumulated particles can be removed by opening the drainage valve, allowing gravity flow to drain and clean the filter.

Research carried out by Cinara over more than $15 \mathrm{yr}$ showed that different MSF alternatives that were tested, including UGF (filtration rate, $V_{\mathrm{f}}=0.6 \mathrm{~m} \mathrm{~h}^{-1}$ ) and SSF (operating at $0.15 \mathrm{~m} \mathrm{~h}^{-1}$ ), were able to produce effluents with a low microbial risk (Galvis, 1999). Research also explored the use of coagulation and flocculation with UGF, called CF-UGF, focusing, in pilot plants, on the combination with rapid filters $(\mathrm{RF})$. The results showed a reduction in the consumption of coagulants by up to $30 \%$ compared to the conventional system of coagulation, flocculation and high rate sedimentation (Cinara and IRC, 1996).

Other research into CF-UGF has emphasized the laboratory variables and the removal efficiencies. Richter and Moreira (1981) reported that a flocculation time of $3-5 \mathrm{~min}$ in a UGF is equivalent to a time of $15 \mathrm{~min}$ in the jar test under laboratory conditions and $25 \mathrm{~min}$ in non-compartmentalized flocculation units in full-scale plants. Santamaría (1999) showed that, using UGF, the flocculation time can be reduced by up to $60 \%$ compared to mechanical flocculators; Salazar and Ocampo (1999) found that in CF-UGF, producing the same water quality would require between 10 and 20 times less retention time compared to a sludge blanket clarifier; Kawamura (1985), working on pilot units with UGF and RF, reported a turbidity removal of 50\%; Ahsan (1995) found that horizontal gravel filtration (HGF) with coagulation removes more particles compared to the HGF without chemicals. In addition, studies with different packed gravel beds found that a stratified bed is more efficient than a uniform bed (Attakoya et al., 1991). Di Bernardo and Sabogal (2009) have further refined some of the parameters for design and operation and maintenance, but have only applied these at pilot scale. The use of CF-UGF with MSF has had few fullscale applications. Full-scale experiences using UGF based on conventional technology with rapid filtration as a final stage were reported by Kardile (1981), working with a $V_{\mathrm{f}}=4-10 \mathrm{~m} \mathrm{~h}^{-1}$ and turbidity levels between $300-500 \mathrm{NTU}$, achieving construction costs between 30 to $50 \%$ less than conventional systems of equal capacity. Bhole (1981) reported a velocity gradient in a truncated pyramid filter of $G=1230 \mathrm{~s}^{-1}$ at the bottom layer and $35 \mathrm{~s}^{-1}$ at the upper layer with a $V_{\mathrm{f}}=11.3 \mathrm{~m} \mathrm{~h}^{-1}$. More recent studies indicated that aluminium residual has not shown any effects on biological activity in SSF, when coagulation with aluminium sulphate has been used, Dorea and Clarke (2006). This indicates that the addition of coagulant with UGF has potential to improve the performance of MSF during variations in influent water quality, conserving biological processes in the following stages. Consequently full-scale evaluations are necessary to better understand the design variables and operation and maintenance conditions.
The community of Colinas de Arroyo Hondo, located in a rural area of Yumbo municipality, Colombia, had a treatment plant functioning with the processes of coagulation, flocculation, sedimentation, rapid filtration and disinfection with chlorine and ultraviolet light. However, in field studies on water quality in the distribution network, biofilms were found in the pipes, which generated problems of re-growth of micro-organisms in the water supplied to the users (average values of $2183 \mathrm{CFU}(100 \mathrm{ml})^{-1}$ for heterotrophic bacteria, $7 \mathrm{CFU}(100 \mathrm{ml})^{-1}$ for E-coli, and $39 \mathrm{CFU}(100 \mathrm{ml})^{-1}$ for total coliforms were also found at four points in the distribution network), (Sánchez et al., 2006b). In the treatment plant, which had been operating for $4 \mathrm{yr}$, failures were identified in its functioning, allowing solids and micro-organisms to pass into the distribution system. After an investigation, the treatment system was redesigned and rebuilt to CF-UGF with MSF. This new system has been in operation for $7 \mathrm{yr}$ at the time that this evaluation study was carried out.

This paper assesses the performance and the design aspects of the CF-UGF units followed by UGF and SSF, defining influent turbidity levels to allow operation with and without coagulant, taking advantage of the SSF as the final stage of filtration for the removal of microorganisms.

\section{Materials and methods}

\subsection{Set-up of the treatment system}

In Fig. 1 the set-up of the CF-UGF MSF plant is shown. The system operation is performed by pumping raw water to the plant and then, after treatment, pumping it into the distribution network. The system uses two pumping flow rates: $61 \mathrm{~s}^{-1}$, which is the maximum capacity for $12 \mathrm{~h}$ during the day and $31 \mathrm{~s}^{-1}$ for another $12 \mathrm{~h}$ at night. The treatment plant consists of 5 components. Raw water passes through the flow control unit in the dynamic roughing filter (DRF), whose main function is to protect the next steps from excessive loads of suspended solids and turbidity. Filtered water flows into a rapid mixing chamber (RMC), where the coagulants are dosed. Afterwards, the water enters the CF-UGF stage which consists of 2 units in parallel, where the processes of coagulation, flocculation, sedimentation and filtration of destabilized particles occur. Water is collected in a front weir to later enter the UGF where remaining flocculated particles are removed in the different layers of gravel. From there, the water enters the SSF stage for final removal of suspended particles and microorganisms.

The RMC unit allows a proper rapid mixing time and a velocity gradient, while the CF-UGF unit facilitates flocculation and deposition of particles. The hydraulic RMC operates through a rectangular weir that allows free flow of water to form a hydraulic jump for mixing the coagulant with the raw water. Above the RMC a channel provided with holes is installed to distribute the coagulant and initiate the destabilization of the particles, which will be removed in the CF-UGF 


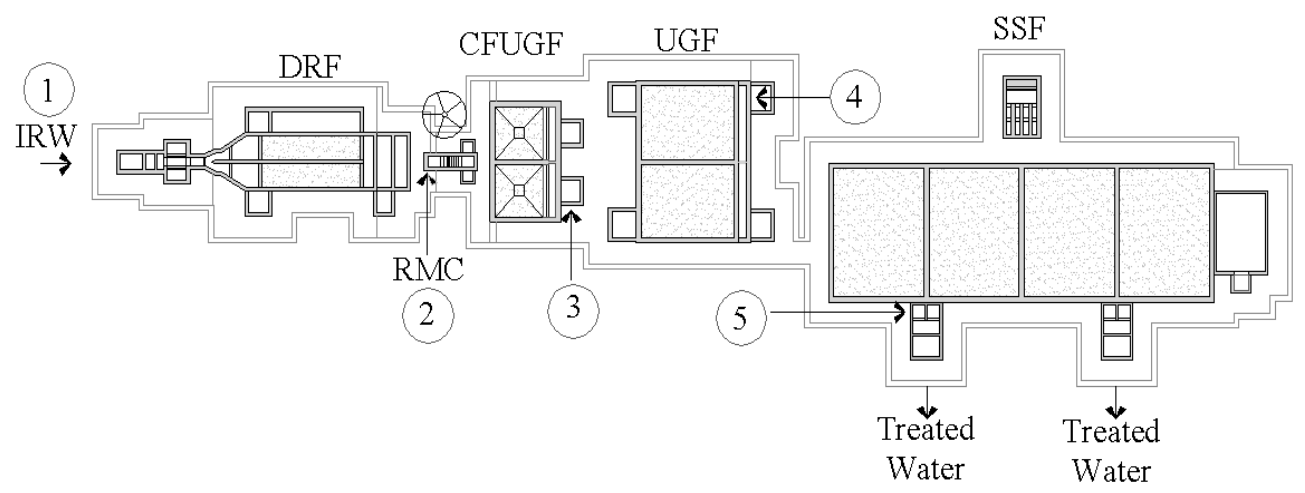

Figure 1. Layout of the treatment system (1-5: monitoring points of water quality).

Table 1. Parameters and formulae.

\begin{tabular}{|c|c|c|}
\hline Parameter & Formulae & Value \\
\hline \multicolumn{3}{|l|}{$\mathrm{RMC}$} \\
\hline Length to the mixing point & $L_{\mathrm{m}}=1+0.5 h_{v}\left(P_{v} / h_{v}\right)^{0.54}(1)$ & $0.17 \mathrm{~m}$ \\
\hline $\begin{array}{l}\text { Velocity gradient for rapid } \\
\text { mixing }\end{array}$ & $G=\left(\gamma E_{p} / \mu T_{\mathrm{m}}\right)^{0.5}(2)$ & $1282 \mathrm{~s}^{-1}$ \\
\hline Average mixing time $\left(T_{\mathrm{m}}\right)$ & $T_{\mathrm{m}}=L_{r} / V_{\mathrm{ap}}(3)$ & $0.31 \mathrm{~s}$ \\
\hline \multicolumn{3}{|l|}{ CF-UGF } \\
\hline $\begin{array}{l}\text { Average velocity gradient } \\
\text { CF-UGF (Di Bernardo and Sabogal, } \\
\text { 2009) }\end{array}$ & $G=\sqrt{\frac{(\gamma)\left(V_{\mathrm{ap}}\right)\left(J_{\mathrm{mg}}\right)}{(\mu)\left(\epsilon_{o}\right)}}(4)$ & $28.5-3.1 \mathrm{~s}^{-1}$ \\
\hline $\begin{array}{l}\text { Unit head loss in the } \\
\text { porous medium (Ergun, 1952) }\end{array}$ & $J=\frac{150 v\left(1-\epsilon_{o}\right)^{2}\left(V_{\mathrm{ap}}\right)}{g\left(\epsilon_{o}\right)^{3}\left(C_{\mathrm{s}}\right)\left(D_{\mathrm{mg}}\right)^{2}}+\frac{1.75\left(1-\epsilon_{o}\right)\left(V_{\mathrm{ap}}\right)^{2}}{g\left(\epsilon_{o}\right)^{3}\left(C_{\mathrm{s}}\right)\left(D_{\mathrm{mg}}\right)}(5)$ & $0.0016-0.0009 \mathrm{~m} \mathrm{~m}^{-1}$ \\
\hline $\begin{array}{l}\text { Reynolds number in the } \\
\text { porous medium (Dinoy, } \\
\text { 1971) }\end{array}$ & $R=\frac{\rho x V_{\mathrm{f}} x k^{1 / 2}}{\mu}(6)$ & $732-41$ \\
\hline
\end{tabular}

and the UGF. The RMC is divided into 3 compartments, one for arrival and energy dissipation, one for mixing and one for the outlet of the coagulated water to the CF-UGF. Table 1 lists the parameters considered for the design of the unit, the formulae and the values obtained during the operation, while Fig. 2 shows the layout of the CF-UGF unit.

The CF-UGF step consists of 2 units in parallel and forms the third component in the treatment scheme. The system has 4 layers of gravel bed and was designed as a truncated pyramid to facilitate variation in the velocity gradient, producing a variable gradient from the highest to the lowest value from the bottom to the surface of the unit. In Table 2 the values of the velocity gradient for two flow operations are listed, de- pending on the properties of the filter bed and the average fluid velocity in each gravel layer, the cross-sectional area of the filter and the head loss in the bed. The calculation of the velocity gradient was done by Eq. (4) (see Table 1) and the head loss by Eq. (5) proposed by Ergun (1952), which is valid for any flow regime as long as the bed is not fluidized (Di Bernardo and Sabogal, 2009).

The flocculation gradient is greater at the bottom of the bed, decreasing towards the top of the filter, basically to promote the formation of flocs (Fair et al., 1984). It should be noted that the velocity gradient values were lower than those reported by Ahsan (1995) (200-300 s ${ }^{-1}$ ) because the filtration rate in CF-UGF was lower. The Reynolds numbers 


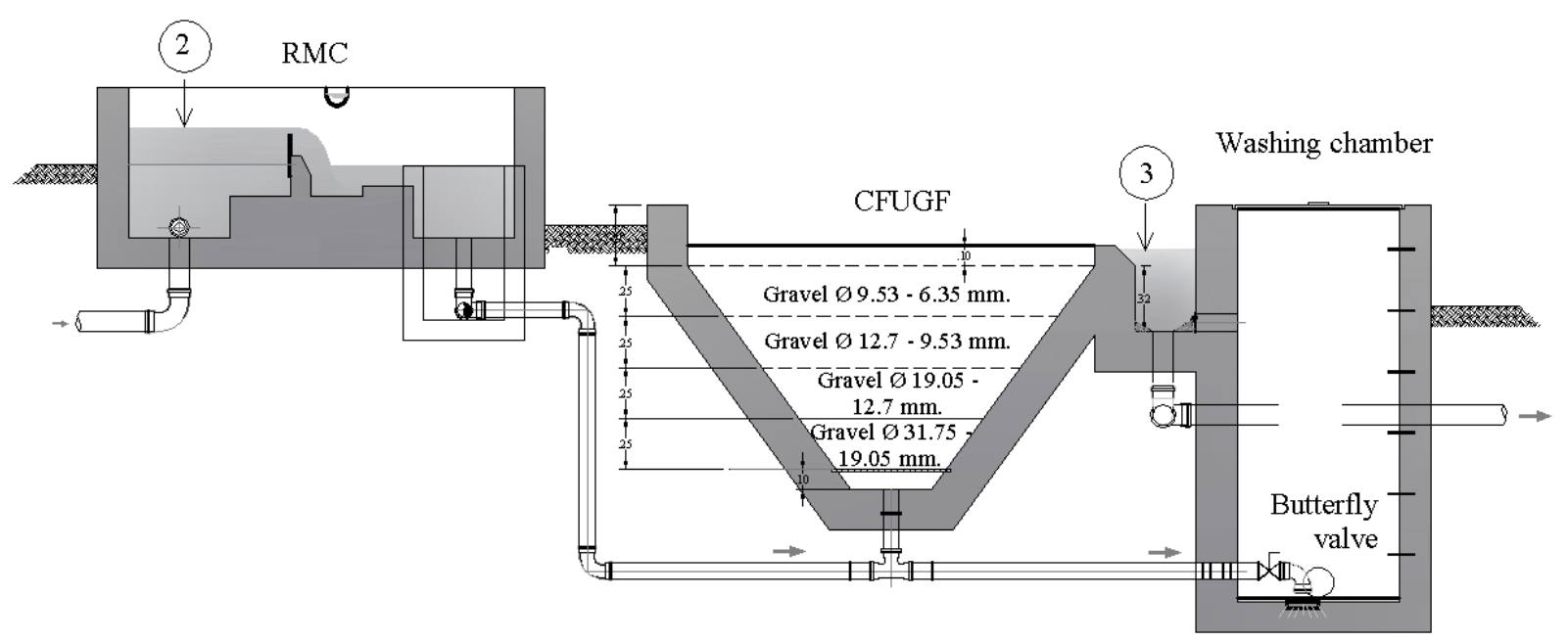

Figure 2. CF-UGF Unit Scheme (2-3: monitoring points of water quality).

Table 2. Velocity gradients in the CF-UGF for the 2 flows of operation.

\begin{tabular}{|c|c|c|c|c|c|c|c|c|c|c|}
\hline \multirow{2}{*}{$\begin{array}{l}\text { Filter media } \\
\text { size } \mathrm{mm}\end{array}$} & \multirow[t]{2}{*}{$\varepsilon$} & \multirow[t]{2}{*}{$D_{\mathrm{mg}}(\mathrm{m})$} & \multicolumn{4}{|c|}{ Flow $31 \mathrm{~s}^{-1}$} & \multicolumn{4}{|c|}{ Flow $61 \mathrm{~s}^{-1}$} \\
\hline & & & $\begin{array}{l}V_{\text {ap }} \\
\left(\mathrm{m} \mathrm{s}^{-1}\right)\end{array}$ & $\begin{array}{l}J \\
\left(\mathrm{~m} \mathrm{~m}^{-1}\right)\end{array}$ & $\begin{array}{l}G \\
\mathrm{~s}^{-1}\end{array}$ & $R e$ & $\begin{array}{l}V_{\mathrm{ap}} \\
\left(\mathrm{m} \mathrm{s}^{-1}\right)\end{array}$ & $\begin{array}{l}J \\
\left(\mathrm{~m} \mathrm{~m}^{-1}\right)\end{array}$ & $\begin{array}{l}G \\
\mathrm{~s}^{-1}\end{array}$ & $R e$ \\
\hline $31.7-19.0$ & 0.31 & 0.0317 & 0.00375 & 0.0016 & 14.2 & 366 & 0.0075 & 0.0032 & 28.5 & 732 \\
\hline $19.0-12.7$ & 0.38 & 0.0191 & 0.0014 & 0.0007 & 5.3 & 124 & 0.0029 & 0.0015 & 11 & 257 \\
\hline $12.7-9.5$ & 0.40 & 0.0111 & 0.00075 & 0.0009 & 4.2 & 43 & 0.0015 & 0.0019 & 8.5 & 86 \\
\hline $9.5-6.3$ & 0.42 & 0.0079 & 0.00045 & 0.0009 & 3.1 & 20 & 0.0009 & 0.0018 & 6.3 & 41 \\
\hline
\end{tabular}

$T=22.8^{\circ} \mathrm{C}, \gamma=9737 \mathrm{~N} \mathrm{~m}^{-1}, \mu=9.44 \times 10^{-4} \mathrm{~N} \mathrm{~m} \mathrm{~s}^{-2} ; v=9.47 \times 10^{-7} \mathrm{~m}^{2} \mathrm{~s}^{-1}, C_{\mathrm{s}}=0.81$.

indicate that the units work in the hydraulic transition regime; values obtained above 10 indicate a stable inertial regime for flocculation in the porous medium, as reported by Wright (1968). For the calculation of the head loss in the filter the Ergun equation was used.

The calculations for each barrier of the treatment system were done on the basis of the design parameters presented in Table 3 and the dimensions of each barrier in Table 4.

\subsection{Monitoring water quality and system operation}

During the study, the raw water was monitored for the following parameters: turbidity, true colour, E-coli, total coliforms, heterotrophic bacteria plate count (HPC) and $\mathrm{pH}$. The water quality parameters and related methods are listed in Table 5. Measurements of the head loss $\left(h_{\mathrm{f}}\right)$ over the filter bed were done for short periods of operation (4-6h), when coagulants were applied. However, when operating without coagulant, daily measurements were done during periods of 8 days, according to the schedule defined by the plant operators for cleaning the CF-UGF and UGF. This is because with time large quantities of solids will accumulate within the gravel bed and then filter resistance will increase gradually and the water level within the inlet chamber will rise to a maximum $h_{\mathrm{f}}$. To facilitate the measurements of $h_{\mathrm{f}}$, steel rules were installed in the inlet chamber, taking care that the zero of the rule coincides with the water level in the chamber for the no-flow condition.

The dose of coagulant for operation of the CF-UGF system was previously defined according to studies developed by Cinara (2004). In these studies two types of jar tests were carried out: (a) to define basic parameter such as rapid mixing time, gradient of rapid mixing, slow gradient mixing, slow mixing time, and sedimentation time; the rapid mixing intensity and the slow mixing during the jar test were expressed in the velocity gradient $G\left(\mathrm{~s}^{-1}\right)$ following the method described in CEPIS (2004) and were used for a first approximation of the velocity gradient in the CF-UGF and (b) one second set of jar tests were done with raw water of the source to define the optimal dose of coagulant (turbidity up to $100 \mathrm{NTU}$ ), following the method presented by Di Bernardo and Sabogal (2009), where rapid mixing is done using jar test equipment with 2-L glass jars. The coagulant used was $50 \%$ liquid aluminium sulphate diluted with water to $2 \%$, and was added for a period of $60 \mathrm{~s}$ at a velocity gradient greater than $300 \mathrm{rpm}$. After rapid mixing, water was extracted and filtered 
Table 3. Treatment barriers and design parameters.

\begin{tabular}{|c|c|c|c|c|c|}
\hline \multirow[t]{2}{*}{ Criteria } & \multicolumn{5}{|c|}{ Treatment Stage } \\
\hline & DRF & $\mathrm{RMC}$ & CF-UGF & UGF & SSF \\
\hline Design period (years) & 15 & 15 & 15 & 15 & 15 \\
\hline Operation time $(\mathrm{h})$ & 24 & 24 & 24 & 24 & 24 \\
\hline Number of units in parallel & 2 & 1 & 2 & 2 & 4 \\
\hline Flow per unit $\left(1 \mathrm{~s}^{-1}\right)$ & 3 & 6 & 3 & 3 & 1.5 \\
\hline Filtration rate $\left(\mathrm{m} \mathrm{h}^{-1}\right)$ & 3 & & $3.2-27$ & 1.0 & 0.30 \\
\hline Backwashing rate $\left(\mathrm{m} \mathrm{h}^{-1}\right)$ & 20 & & 20 & 20 & \\
\hline Area by unit $\left(\mathrm{m}^{2}\right)$ & 3.6 & & 4 & 10.8 & 18 \\
\hline \multicolumn{6}{|l|}{ Gravel } \\
\hline Length (m) & 0.6 & & 1 & 1.1 & 0.2 \\
\hline Size $(\mathrm{mm})$ & $25.4-3.2$ & & 19-6.3 & $25.4-3.2$ & 12.5 \\
\hline \multicolumn{6}{|l|}{ Sand } \\
\hline Length (m) & - & - & - & - & 0.85 \\
\hline$d_{10}(\mathrm{~mm})$ & & & & & $0.15-0.35$ \\
\hline$C_{u}$ & - & - & - & - & $2-3.5$ \\
\hline
\end{tabular}

Table 4. Dimensions of each barrier.

\begin{tabular}{lllllll}
\hline \multirow{2}{*}{ Treatment barrier } & \multirow{2}{*}{\begin{tabular}{l} 
Number of \\
\cline { 3 - 4 }
\end{tabular}} & \multicolumn{3}{c}{ Dimensions } & \multirow{2}{*}{ Flow } & Material \\
\cline { 3 - 4 } & units & $L(\mathrm{~m})$ & $A(\mathrm{~m})$ & $H(\mathrm{~m})$ & $\left(1 \mathrm{~s}^{-1}\right)$ & structure \\
\hline Input chamber & 1 & 5.15 & 0.6 & 0.7 & 6.0 & Concrete \\
DRF & 2 & 4.0 & 0.9 & 0.8 & 3.0 & Concrete \\
RMC & 1 & 2.2 & 0.4 & $0.5-0.7$ & 6.0 & Concrete \\
CF-UGF* & 2 & 2.0 & 2.0 & 1.4 & 3.0 & Concrete \\
UGF & 2 & 3.8 & 2.84 & 1.3 & 3.0 & Concrete \\
SSF & 4 & 3.7 & 4.7 & 1.75 & 1.5 & Concrete \\
\hline
\end{tabular}

$L$ : length; $A$ : width; $H$ : depth; ${ }^{*}$ Bottom Area: $0.16 \mathrm{~m}^{2}$ Surface Area: $4.0 \mathrm{~m}^{2}$

Table 5. Water quality parameters and analysis method.

\begin{tabular}{lll}
\hline Parameters & Method & $\begin{array}{l}\text { Limit of } \\
\text { detection }\end{array}$ \\
\hline Total coliform & 9222B, filtration $\times$ membrane & 0 \\
E-coli & $9222 \mathrm{~B}$, filtration $\times$ membrane & 0 \\
HPC & $9215 \mathrm{~A}$, discharge in plate & 0 \\
Turbidity & 2130B & 0.1 \\
Aluminium & 3500-Al B & 0.03 \\
pH & 4500 H + & 2 \\
True colour & 2120C & 1 \\
TOC & 5310 B & 0.18 \\
(APHA, AWWA, WPCF, 2005) & \\
\hline
\end{tabular}

in a funnel containing filter paper Whatman 40 (pore size $8 \mu \mathrm{m})$, to obtain a volume sufficient to realize analyses.

Tracer tests were performed according to the methodology described by Pérez and Galvis (1990), in order to understand the hydraulic performance of the CF-UGF and UGF units.
Trials were conducted following the experimental stimulusresponse method, in which a tracer, easily detectable and not involved in any of the physical and chemical processes that may alter the actual fluid hydrodynamics and with a known concentration, is injected into the influent (Rocha et al., 2000). The concentration curve of the tracer was analysed to determine the portion of plug flow, dead zones, and the fraction that works as a completely mixed flow. These tests were conducted using sodium chloride. The substance was dosed continuously through a constant hydraulic head dispenser with a sodium chloride concentration between 50 $100 \mathrm{mg} \mathrm{L}^{-1}$. The dosing period was three times the theoretical retention time of each unit and the response was measured at the output of each unit by means of electrical conductivity. Measurements were taken after the CF-UGF unit every 2 min. Results were analysed with the mathematical model Wolf-Resnick, the Morril Index (relationship between the time between the $90 \%$ and the $10 \%$ passage of the tracer), and the model of completely mixed reactors in series (CMRS), Pérez and Galvis (1990). Wolf-Resnick model 
Eq. (7) indicates that by plotting the fraction of tracer remaining in the filter $(1-F(t))$ versus $t t_{o}^{-1}$ (relationship between measured time and the theoretical retention time), it is possible to estimate the values $\theta$ and $\tan \alpha$ (the slope of the straight line), and to identify the characteristics of the reactor using Eqs. (8) to (11). CMRS model was analyzed using Eq. (12), where $n$ is the number of reactors in series and $C C_{o}^{-1}$, is the relationship between the concentration of tracer which remains in the reactor at a time and the concentration of tracer applied.

$\log 1-F(t)=-\tan \alpha\left[\left(t t_{o}^{-1}\right)-p(1-m)\right]$

$\operatorname{Tan} \alpha=(0.434 \cdot p) /(\theta \cdot(1-p))$

Plug flow $(\theta): \theta=p(1-m)$

Dead zones $(m): m=1-(\theta / p)$

Mixed flow $\left(M_{\mathrm{f}}\right): M_{\mathrm{f}}=(1-p)(1-m)$

CMRS model : $\frac{C}{C_{o}}=n\left[\frac{\left(n \cdot \frac{t}{t_{o}}\right)^{n-1}}{(n-1) !}\right]\left(e^{-n \cdot \frac{t}{t_{o}}}\right)$

The porosity $\left(\varepsilon_{0}\right)$ of the filter material was determined following the procedure defined by Ives (1990): first, the mass $(M)$ occupied by the sample of gravel in a container of known volume and the apparent volume $(V)$ occupied by the gravel in the container were both measured; then the density $\left(\rho_{s}\right)$ of the gravel was determined by the ratio between the mass of the sample and the volume occupied by the sample. The porosity was calculated by Eq. (13).

$\varepsilon_{0}=1-M / \rho_{s} V$

The filter cleaning procedure was the following: the water inlet to the unit was interrupted; without removing the supernatant water the surface of the gravel bed was cleaned manually with a shovel, stirring the surface layer of the filter to remove solid material adhering to the gravel; the supernatant water with the removed deposits from the top of the filter bed was discharged through a front weir; then the filter was prepared for removal of the deposits in the filter by adding water to the unit by opening the flow control valve in the inlet chamber to restore the supernatant water layer and increasing its height to a level of water between $20-25 \mathrm{~cm}$ above the gravel in the main compartment; this increased height adds some pressure for the cleaning procedure, in which fast drainage was carried out by quickly opening and closing (some 10 times) the butterfly valve on the underdrains; the unit was thereafter refilled with water and the cleaning and drainage procedure was repeated for adequate cleaning of gravel; then the filter was put back into operation.

The flow rate $(Q)$ of the draining procedure in the UGF units was determined by the following procedure: (a) the unit was filled to the maximum level of the top; (b) the water flow into the filter was interrupted; (c) the surface area was measured $(A)$; (d) the butterfly valve was opened until the water level lowered by $5 \mathrm{~cm}$; (e) the declining water level $(\Delta h)$ was measured over time $(t)$ and (f) the initial flow rate was set by the expression $Q=\Delta h \cdot A / t\left(\mathrm{~m}^{3} \mathrm{~s}^{-1}\right)$.

\section{Results and discussion}

\subsection{Water quality of the source water}

The water source is a small mountain river (the Arroyo Hondo River) which drains an area that has problems of deforestation and erosion, strong activity in the basin of rocky material exploitation for construction and discharge of untreated wastewater. The behaviour of microbiological parameters over a 3-month period indicated that the source has, according to Lloyd and Helmer (1991) and WHO (2011), a high microbiological risk, because faecal coliform values at all times exceeded $1000 \mathrm{CFU}(100 \mathrm{ml})^{-1}$. E-coli bacteria were below $4.2 \operatorname{logs} \mathrm{CFU}(100 \mathrm{ml})^{-1}$ for $95 \%$ of the time, but were never less than $3.2 \operatorname{logs} \mathrm{CFU}(100 \mathrm{ml})^{-1}$. The average values of HPC and total coliforms were $5.3 \operatorname{logs} \mathrm{CFU}$ $(100 \mathrm{ml})^{-1}$ and $5.1 \operatorname{logs} \mathrm{CFU}(100 \mathrm{ml})^{-1}$, respectively.

The behaviour of turbidity in the source was measured for a period of one year. This parameter, which is easy to measure, is a good indicator to control the system and facilitates decision-making by the operator. The results indicated that the turbidity in the source did not exceed 100 NTU for $97 \%$ of the time, while the turbidity was lower than $25 \mathrm{NTU}$ for $75 \%$ of the time. Minimum values of 3 NTU were recorded during the summer period and maximum values of $350 \mathrm{NTU}$ during the rainy season. Turbidity peaks were of short duration (4-6h) but sometimes lasted up to $24 \mathrm{~h}$. For $95 \%$ of the time the true colour level in the river was below 25 UPC and at no time the level dropped below 5 UPC.

\subsection{Coagulant dosage}

The basic parameters defined for the operation with coagulant were as follows (Cinara, 2004): rapid mixing time $60 \mathrm{~s}$, gradient of rapid mixing $300 \mathrm{rpm}\left(G=280 \mathrm{~s}^{-1}\right)$, slow gradient mixing of $60 \mathrm{rpm}\left(G=28 \mathrm{~s}^{-1}\right)$, slow mixing time $25 \mathrm{~min}$, and sedimentation time of $20 \mathrm{~min}$. Figure 3 presents the coagulant dose of aluminium sulphate for different turbidity levels, applied to the operation with coagulant based on previous studies developed by Cinara (2004). The dosage behaves as a logarithmic function and a little variation in the dose of coagulant is presented for affluent turbidities between 60 100 NTU. The optimum $\mathrm{pH}$ was in the range of 6.6-7.6 for an alkalinity between $59-133 \mathrm{mg}\left(\mathrm{CaCO}_{3}\right)^{-1}$. The $\mathrm{pH}$ range of the water source has facilitated an efficient and low cost operation because only very small changes occurred during the coagulation-flocculation process, thus avoiding the need for $\mathrm{pH}$ adjustment. The dosing conditions as shown in Fig. 3 


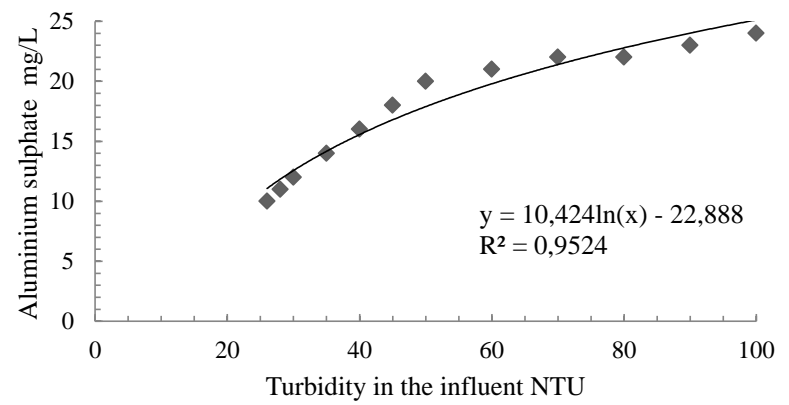

- Jar test data

- Logarithmic

Figure 3. Aluminium sulphate dose as a function of influent turbidity in CF-UGF Unit.

are clearly within the range suggested by CEPIS (2004), of $3-30 \mathrm{mg} \mathrm{L}^{-1}$ of aluminum sulfate and a $\mathrm{pH}$ close to 7 , which suggest that prevailing coagulation mechanism is due to charge neutralization of the aluminium hydroxide. Dosing of aluminum sulphate is carried out by a dispenser at the point of greatest turbulence in the RMC; the concentration of solution of aluminum sulphate was $2 \%$, which is in line with the recommendation of CEPIS (2004) which suggests a coagulant concentration between 1-2\% for water treatment plants. This level of concentration in combination with sufficient turbulence, allows for a good coagulant dispersion which facilitates its coming into quick contact with a large number of particles (Di Bernardo and Sabogal, 2009).

\subsection{Hydraulic behaviour of CF-UGF units}

Figure 4 shows the results of the mathematical model WolfResnick. The model results for CF-UGF indicate that the system worked with a plug flow fraction of $51 \%$, a mixed fraction of $46 \%$ and a dead zone fraction of $3 \%\left(r^{2}=0.90\right)$. Taking into account the dead zones in the CF-UGF, the velocity gradient in the unit varied between 3.2 and $29.4 \mathrm{~s}^{-1}$, which is close to the value calculated in Table 2 and obtained in the jar test by Cinara (2004) to define the coagulant dose. The Morrill Index (MI) was 1.82, which suggests, according to experiments by Pérez and Galvis (1990), the presence of plug and mixed flow in the CF-UGF unit. Figure 5 presents the results of the CMRS model. The continuous lines show the hydraulic behaviour with $n$ reactors in series, while the dotted line represents the measurements at the CF-UGF unit. When comparing the results of the theoretical model with experimental data, the hydraulic behaviour of the reactor CF-UGF tends to $n=6$ reactors in series (see continuous black curve, Fig. 5), confirming the presence of a relative plug flow. The mean residence time $\left(t_{\mathrm{m}}\right)$ was estimated from the experimental curve, determining the centroid under the curve, the mean residence time for the CF-UGF was $19.7 \mathrm{~min}$ for the flow

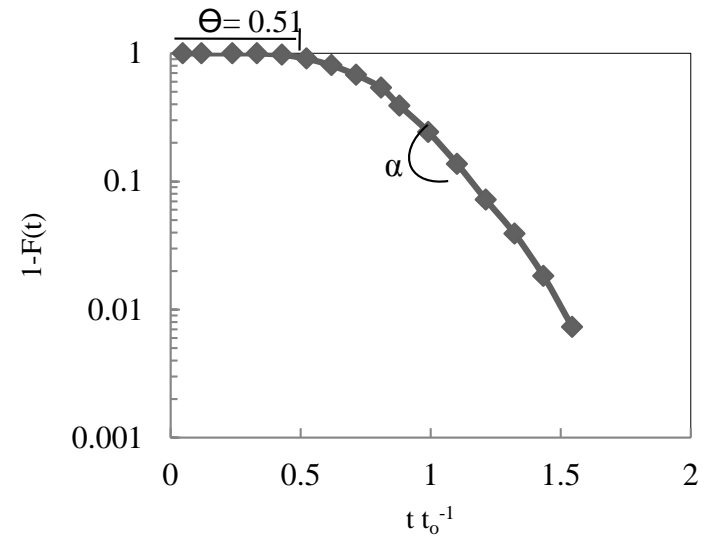

$\log 1-F(t)=-0.95\left(t t_{o}^{-1}\right)+1.24\left(r^{2}=0.902\right)$

$\operatorname{Tan} \alpha=0.95 ; \theta=0.51 ; p=0.53 ; m=0.03 ; \mathrm{Mf}=0.46$

Figure 4. Hydraulic Wolf-Resnick model results for the CF-UGF.

of $31 \mathrm{~s}^{-1}$ while theoretical retention time was $19 \mathrm{~min}$. These differences may be explained by the presence of dead zones and implies that the curve of distribution residence time has a tail and therefore the time will be displaced in the time axis (Fig. 5), the fluid elements that were trapped in the dead zones is conducted very slowly and will have a much larger residence time.

\subsection{Removal of turbidity in the operation without coagulant}

The operation of the CF-UGF without coagulant dosing was used in dry periods. Figure 6 shows the frequency of turbidity in raw water and after different treatment barriers, including DRF, CF-UGF, UGF and SSF. The CF-UGF units produced an effluent between 2.5-7.5 NTU, with mean removal efficiency of $46 \%$, while for $78 \%$ of the time the UGF showed turbidity levels lower than 1 NTU and another $22 \%$ were between 1.5-2 NTU. SSF units processed water with $0.3 \mathrm{NTU}$ for $98 \%$ of the time. CF-UGF and UGF always produced water with turbidity levels below $10 \mathrm{NTU}$, which is the guideline value of inflow water to the SSF units, according to Di Bernardo and Sabogal (2009) and to Galvis et al. (1999) who add the requirement that filtration rates should be lower than $0.20 \mathrm{~m} \mathrm{~h}^{-1}$ in SSF units. In this case it was a little higher because the system operated at filtration velocities of between 0.15 and $0.30 \mathrm{~m} \mathrm{~h}^{-1}\left(3-61 \mathrm{~s}^{-1}\right)$.

\subsection{Removal of turbidity in the operation with coagulant}

Figure 7 shows the frequency of turbidity in raw water and different treatment barriers, when the CF-UGF is operated with coagulants. The application of coagulant in the RMC varied as indicated in Fig. 3. In the effluent CF-UGF units, for $97.2 \%$ of the time turbidity levels lower than $10 \mathrm{NTU}$ 


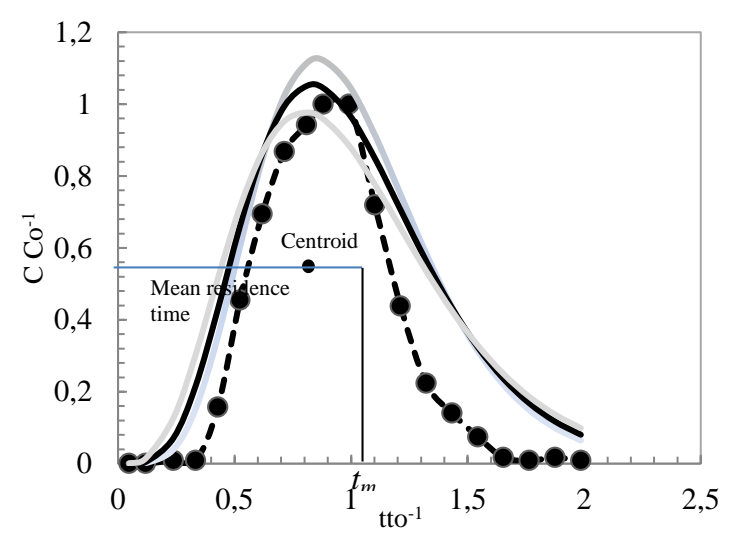

-๑- Experimental $\longrightarrow \mathrm{n}=5 \quad \mathrm{n}=6 \quad \mathrm{n}=7$

Figure 5. CMRS model for CF-UGF.

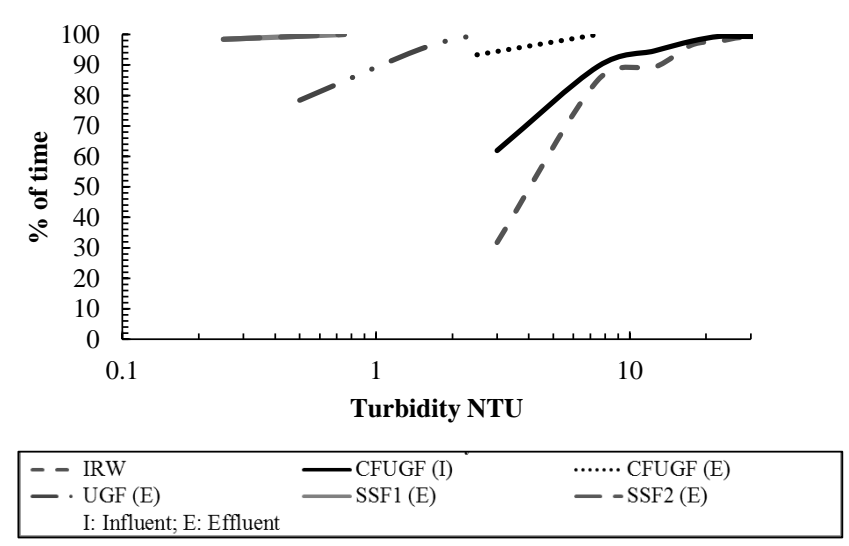

Figure 6. Frequency of turbidity levels (operation without coagulant).

were achieved, while the maximum value of turbidity in the effluent in this step ranged between 15-20 NTU for $1.4 \%$ of the time. The UGF showed turbidity levels lower than 6 NTU for $100 \%$ of the time, thereby facilitating the operation of the SSF, which produced water with turbidity below 1 NTU for $98 \%$ of the time. The addition of coagulant in the CFUGF enabled water with turbidity levels below 10 NTU after UGF to be obtained. Increments in turbidity levels, which occur basically in the rainy season, could be managed in the treatment plant by the CF-UGF unit, which contributed to an effective operating system, preventing reductions in the SSF filtration runs. Additionally, stops in the operation of the treatment plant were prevented.

The removal efficiency of turbidity in the CF-UGF with coagulant was between 85 and $96 \%$, which is higher compared to operating without coagulant, and average efficiency of turbidity in the CF-UGF was $46 \%$, ranging between $21-$

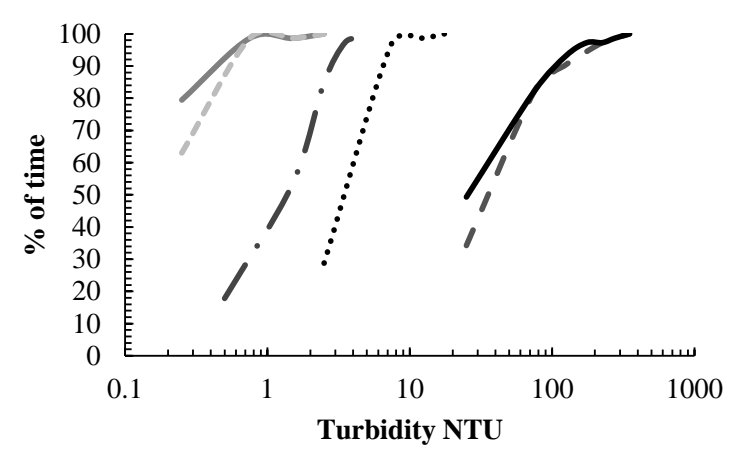

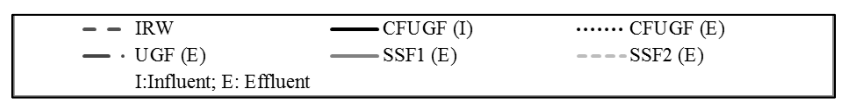

Figure 7. Frequency of turbidity levels (operation with coagulant).

$76 \%$. The removal efficiencies in CF-UGF with velocity gradients between $28.5-3.1 \mathrm{~s}^{-1}$ (for 3 and $61 \mathrm{~s}^{-1}$ ) was consistent with the findings of Di Bernardo and Sabogal (2009), who established that the gradient must be less than $100 \mathrm{~s}^{-1}$. The efficiency in the removal of turbidity can be explained by the good opportunities for contact with particles in the gravel bed, which is consistent with Richter (1987), Attakoya et al. (1991), and Di Bernardo and Cruz (1994).

\subsection{Removal of microorganisms in the operation without coagulant}

When operating without aluminium sulphate, the duration of the filter run was 8 days in the CF-UGF and UGF, regardless whether it achieved the maximum head loss or not (normally head loss is less than $5 \mathrm{~cm}$ in 8 days, to a maximum value of $15 \mathrm{~cm}$ ). The typical removal of microorganisms for a filter run is presented in Table 6 for samples taken in the influent of CF-UGF unit and the effluent of the UGF. The removal efficiency in the CF-UGF and UGF steps was $0.16 \operatorname{logs}$ for total coliforms, 0.16 logs for E-coli and $0.17 \operatorname{logs}$ for HPC, lower than that reported by Galvis et al. (1999), which was probably due the effect of a higher filtration rate. SSF achieved a total reduction of $E$-coli of $3.2 \log$ units, facilitating the work of chlorination as a security barrier. These results are consistent with the WHO (2011) which indicated that the range of log removal of bacteria for SSF must be between 2-6 under presence of schmutzdecke and appropriate: grain size, flow rate, operating conditions (mainly temperature, $\mathrm{pH}$ ), cleaning and refilling and in the absence of short circuiting.

The reduction of the filtration velocity in the UGF from 1.0 to $0.5 \mathrm{~m} \mathrm{~h}^{-1}$ contributed to improved efficiency in the removal of microorganisms. The average removal for total coliforms and E-coli was 0.57 and 0.5 logs respectively in CFUGF and UGF steps, while HPC reached a removal of 0.64 logs. These reductions are close to those reported by Galvis et al. (1999). The average removal in SSF was 3.0 logs. The 
Table 6. Microbiological behaviour without the use of coagulant (UGF: $V_{\mathrm{f}}=1.0 \mathrm{~m} \mathrm{~h}^{-1}, \mathrm{SSF}: V_{\mathrm{f}}=0.30 \mathrm{~m} \mathrm{~h}^{-1}$ ).

\begin{tabular}{llllllllll}
\hline Descriptive statistics & \multicolumn{3}{c}{ Raw water } & \multicolumn{3}{c}{ CF-UGF and UGF effluent } & \multicolumn{3}{c}{ SSF effluent } \\
\cline { 2 - 11 } & TC & EC & HPC & TC & EC & HPC & TC & EC & HPC \\
\hline No data & 9 & 9 & 7 & 9 & 9 & 7 & 10 & 10 & 9 \\
Average & 15131 & 2262 & 202629 & 12227 & 2161 & 139625 & 12 & 0 & 744 \\
Maximum & 25000 & 3600 & 403500 & 19400 & 6700 & 272000 & 68 & 0 & 1900 \\
Minimum & 8000 & 1250 & 120000 & 6100 & 800 & 73000 & 2 & 0 & 100 \\
STD deviation & 6733 & 914 & 123549 & 5893 & 1859 & 80237 & 19.7 & 0 & 651.6 \\
Average log CFU $100^{-1} \mathrm{ml}^{-1}$ removal units & & & & 0.16 & 0.16 & 0.17 & 3.3 & 3.2 & 2.3 \\
\hline
\end{tabular}

TC: Total coliforms (CFU $\left.(100 \mathrm{ml})^{-1}\right)$ EC: E-coli $\left(\mathrm{CFU}(100 \mathrm{ml})^{-1}\right)$ HPC: heterotrophic play count bacteria $\left(\mathrm{CFU}(100 \mathrm{ml})^{-1}\right)$, operational flow $61 \mathrm{~s}^{-1}$.

Table 7. Microbiological behaviour with the use of coagulant (UGF: $V_{\mathrm{f}} 1.0 \mathrm{mh}^{-1}$, SSF: $V_{\mathrm{f}} 0.3 \mathrm{~m} \mathrm{~h}^{-1}$ ).

\begin{tabular}{llllllllll}
\hline \multirow{2}{*}{ Descriptive statistics } & \multicolumn{3}{c}{ Raw water } & \multicolumn{2}{c}{ CF-UGF and UGF effluent } & \multicolumn{2}{c}{ SSF effluent } \\
\cline { 2 - 11 } & TC & EC & HPC & TC & EC & HPC & TC & EC & HPC \\
\hline No data & 5 & 5 & 5 & 5 & 5 & 5 & 5 & 5 & 5 \\
Average & 13240 & 2780 & 110740 & 6070 & 1125 & 41100 & 2.8 & 0 & 540 \\
Maximum & 16050 & 5600 & 160000 & 10100 & 2150 & 47100 & 4 & 0 & 800 \\
Minimum & 8900 & 1200 & 79300 & 3900 & 1000 & 35000 & 1 & 0 & 200 \\
STD deviation & 2746 & 1684 & 31494 & 2402 & 465 & 5290 & 1.3 & 0 & 219 \\
Average log CFU 100 & & & & 0.44 & 0.40 & 0.44 & 3.4 & 3.1 & 3.9 \\
removal units & & & & & & & & & \\
\hline
\end{tabular}

TC: Total coliforms (CFU $\left.(100 \mathrm{ml})^{-1}\right)$ EC: Eschirichia coli (CFU $\left.(100 \mathrm{ml})^{-1}\right)$; HPC: heterotrophic play count bacteria $\left(\mathrm{CFU}(100 \mathrm{ml})^{-1}\right)$, operational flow $61 \mathrm{~s}^{-1}$.

efficiency of the SSF was not influenced by changes in the filtration rate, probably due to the high level of maturity of the filters.

\subsection{Removal of micro-organisms, operation with coagulant}

Table 7 presents the results of operating with coagulant, the data correspond to samples taken in the influent of CF-UGF unit and the effluent of the UGF for a period of $6 \mathrm{~h}$, because when turbidity was less than 30 NTU the coagulant dosing was stopped. The dose of aluminium sulphate corresponded to $10 \mathrm{mg} \mathrm{L}^{-1}$, with an operation flow of $61 \mathrm{~s}^{-1}$. Overall, the pre-treatment with CF-UGF and UGF contributed to the reduction of microbiological load: average $0.44 \log$ removal for total coliforms, $0.40 \log$ removal of $E$-coli, and $0.44 \mathrm{log}$ removal for HPC. Only the CF-UGF unit contributed with average efficiencies for total coliforms equivalent to $0.19 \mathrm{log}$, $0.12 \operatorname{logs}$ for $E$-coli and $0.15 \log$ for HPC. The last stage of treatment, SSF, allowed a total reduction of $3.4 \mathrm{log}$ of total coliforms, $3.1 \log$ for $E$-coli, and $3.9 \log$ of HPC. This suggests that the dosage of aluminium sulphate did not affect the biological activity in pre-treatment and SSF, which is consistent with that reported by Dorea and Clarke (2006).

When comparing operation with and without coagulant an increase in the average efficiency of removal of microorgan- isms, between $0.16-0.17 \log$ to 0.40 to $0.44 \log$ was observed, i.e. in the operation with coagulant the removal efficiency for total coliforms, E-coli and HPC, was 2.75, 2.5 and 2.6 higher respectively compared to the operation without coagulant in the CF-UGF and UGF units.

\subsection{Aluminium, $\mathrm{pH}$, colour and organic matter}

Residual aluminium in the system was low in the effluent of CF-UGF and $53 \%$ was removed in the UGF, so that the concentration in the influent of the SSF varied between 0.07 and $0.09 \mathrm{mg} \mathrm{L}^{-1}$, and the average effluent concentration was $0.04 \mathrm{mg} \mathrm{L}^{-1}$ (STD $0.005 \mathrm{mg} \mathrm{L}^{-1}$ ). This value was lower than the WHO (2011) guidelines, which recommended less than $0.2 \mathrm{mg} \mathrm{L}^{-1}$ for aluminium in drinking water. In a pilot study that examined the impacts of chemical pre-treatment by gravel filters on SSF Dorea and Clarke (2006), reported an average aluminium concentration of $0.041 \mathrm{mg} \mathrm{L}^{-1}$ in the effluent of the SSF and indicated that the chemical improved the overall treatment efficiency. However as indicated by these authors careful control of the coagulation step is needed to avoid carry-over of aluminium to the SSF as this might contribute to possible filter clogging even though turbidities of less than 10 NTU are achieved. In our study however premature clogging did not occur at all and filter runs of SSF were maintained between 50 and 70 days with a maximum 


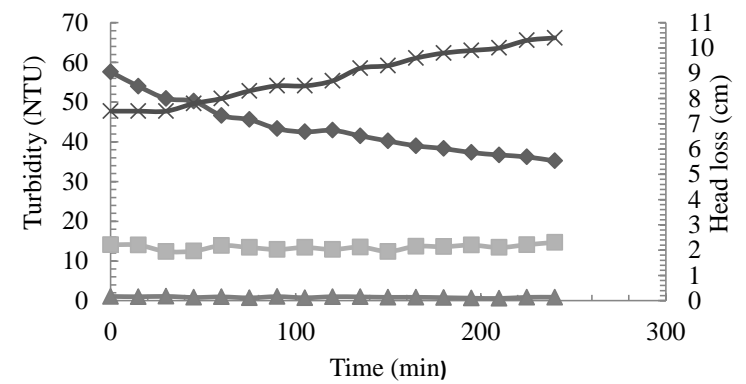

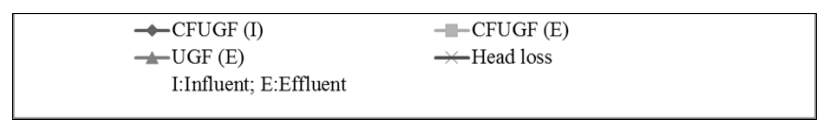

Figure 8. Turbidity in CF-UGF and UGF units and head loss on CF-UGF.

head loss of $0.70 \mathrm{~m}$, which is in line with the range of 20 60 days reported by Schulz and Okun (1984), the minimum of 45 days recommended by Cleasby (1991) and the range of 46-178 days recommended by Galvis et al. (1999). The $\mathrm{pH}$ in the influent varied between 8.2 and 8.5 and between 8 and 8.2 in the effluent of CF-UGF, which is expected not to affect the biological development of the Smutzdecke in the SSF, respect Galvis et al. (1999) reported $\mathrm{pH}$ in the range of 7.1-8.0 for operation of SSF and indicate that the adsorption of virus the sand improves with increasing ion concentration and valence of the cations in solution. The true colour reduction recorded an average efficiency of $54 \%$ in the CF-UGF stage and $57 \%$ in the UGF stage, and the net efficiency of the true colour reduction of the CF-UGF and the UGF stage together was $76 \%$. The organic matter content measured as total organic carbon (TOC) was low, the influent had an average value of $1.1 \mathrm{mg} \mathrm{L}^{-1}( \pm 0.075)$, and the removal efficiency in the CF-UGF and UGF step together was $9 \%$, with an efficiency at the end of the treatment of $28 \%$.

\subsection{Operation and maintenance}

The treatment plant operated without coagulant for turbidity levels below 30 NTU. When influent turbidity was greater than $100 \mathrm{NTU}$, operators interrupted the operation to reduce the turbidity load on the plant and, depending on water needs, operated with coagulant, reducing the filtration rate by half. When rain events occurred and the influent turbidity was greater than $30 \mathrm{NTU}$, a dosage of coagulant was applied. Figure 8 shows the behaviour of turbidity in CF-UGF and UGF and head loss in the CF-UGF units for an event of short duration when the turbidity increased above 30 NTU up to a maximum value of $58 \mathrm{NTU}$, and operation with coagulant was necessary. The monitoring of the head loss was only done in the CF-UGF units. In the UGF unit, there was no change in head loss detected in the relatively short period of the event. The total loss over a period of $4 \mathrm{~h}$ of operation was $3.5 \mathrm{~cm}$
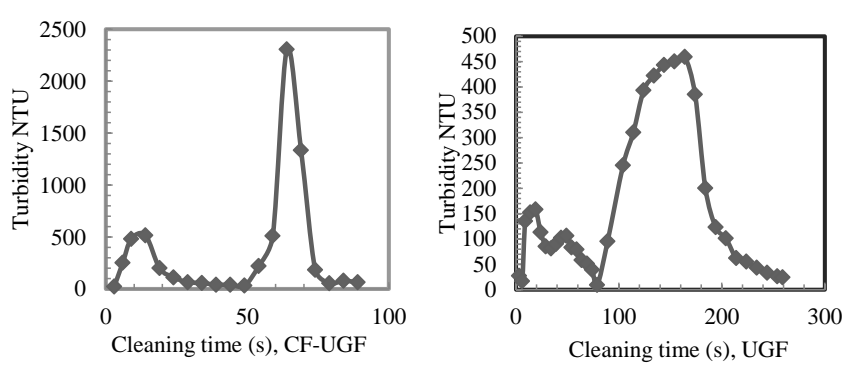

Figure 9. Behaviour of turbidity on a deep clean-up of CF-UGF and UGF.

and did not achieve the maximum value of $20 \mathrm{~cm}$. Table 8 summarizes the operating and monitoring conditions.

Based on the information registered by the operators of the water treatment plant, cleaning frequency for the CF-UGF and the UGF units was every 8 days (without a coagulant dosage). During the rainy period the CF-UGF units, operating with aluminium sulphate, registered cleaning frequencies in the range of 6-100 h. The cleaning frequency of $6 \mathrm{~h}$ was obtained when influent turbidity reached values of above $100 \mathrm{NTU}$, while the 100-h operation mode was observed when influent turbidity levels were between 30-60 NTU.

The behaviour of the cleaning of the CF-UGF in terms of turbidity is presented in Fig. 9. In the CF-UGF, cleaning was done by operating the butterfly valve in such a way that 10 shock waves were created. It can be observed that, for the CF-UGF, in the first $15 \mathrm{~s}$ of the discharge a turbidity peak occurred, for $35 \mathrm{~s}$ the water was clear, and then after $85 \mathrm{~s} \mathrm{a}$ second peak was observed. For the UGF, the solids discharge started immediately to reach a second peak after $150 \mathrm{~s}$, about 5 times higher than the first peak. The behaviour of the water quality in the discharge of the wash water was different from that reported by Wolters (1988) and Cinara and IDRC (1993). When the valve was opened suddenly, the particles which stayed on the filter media experience a change in velocity, whose effect may be to drag the particles to transport to the drainage system.

The flow rate of the drain water for cleaning the filter was variable over time; measurements were done for different heights of water level relative to the position of the butterfly valve. The maximum backwashing rate for the UGF was $9.4 \mathrm{~m} \mathrm{~h}^{-1}$ while for the CF-UGF it was $9.1 \mathrm{~m} \mathrm{~h}^{-1}$.

\subsection{Investment, operation and maintenance costs}

Tables 9 and 10 list the construction costs (year 2011) and operation and maintenance costs (year 2010). The CF-UGF stage and the pre-treatment by UFG represent respectively $7 \%$ and $28 \%$ of the total construction costs of the water treatment plant (see Table 10). The cost per $\mathrm{m}^{3}$ of produced water was US $\$ 0.05$ (discount rate of $12 \%$ for Colombia and project horizon of $15 \mathrm{yr}$ ). Per capita investment costs are US\$18, for an average consumption of $150 \mathrm{lc}^{-1} \mathrm{~d}^{-1}$. The 
Table 8. Summary of operating and monitoring conditions.

\begin{tabular}{|c|c|}
\hline Variable & Value \\
\hline \multicolumn{2}{|l|}{ Operational parameters } \\
\hline Influent turbidity for coagulant dosing & $>30 \mathrm{NTU}$ \\
\hline Maximum turbidity of operation & $\begin{array}{l}\text { Normally } 100 \mathrm{NTU} \text {, } \\
\text { sometimes can } \\
\text { operate with peaks } \\
\text { above } 100 \mathrm{NTU} \\
\text { for short periods of } \\
\text { time }(4-6 \mathrm{~h}) .\end{array}$ \\
\hline $\begin{array}{l}\text { Cleaning period CF-UGF and UGF, } \\
\text { operation without coagulant. }\end{array}$ & Each 8 days \\
\hline Time cleaning of CF-UGF & $15 \min$ \\
\hline Time cleaning of UGF & $45 \mathrm{~min}$ \\
\hline \multicolumn{2}{|l|}{ Monitoring parameters } \\
\hline Coagulant used & $\begin{array}{l}\text { Liquid aluminium } \\
\text { sulphate, type } \mathrm{A} \text {, } \\
50 \% \text { concentration }\end{array}$ \\
\hline Filtration run of the CFUGF with application of coagulant & $6-100 \mathrm{~h}$ \\
\hline Percentage of time with coagulant dosage & $20 \% \mathrm{yr}$ \\
\hline Percentage of operating time without coagulant & $80 \% \mathrm{yr}$ \\
\hline Maximum period of time recorded dosing coagulant & $100 \mathrm{~h}$ \\
\hline Maximum duration of registered plant shutdown & $24 \mathrm{~h}$ \\
\hline Percentage of stops in the year & $3 \%$ \\
\hline Maximum head loss in CF-UGF units & $20 \mathrm{~cm}$ \\
\hline Maximum head loss in UGF units & $15 \mathrm{~cm}$ \\
\hline Maximum backwashing rate CF-UGF & 9.1 to $7.5 \mathrm{~m} \mathrm{~h}^{-1}$ \\
\hline Maximum backwashing rate UGF & 9.4 to $8.4 \mathrm{~m} \mathrm{~h}^{-1}$ \\
\hline
\end{tabular}

costs of O\&M for the use of coagulant are low, representing only $0.3 \%$ of total O\&M costs, because the operator only doses in periods of high turbidity, making the technology attractive. The highest costs of O\&M represent pumping energy and staff. The O\&M costs of US\$ $0.264 \mathrm{~m}^{-3}$ is low (depreciation was included), when compared to the costs of US\$ $1.04 \mathrm{~m}^{-3}$ (includes the average investment costs) for the utility of the city of Cali, close to the community. The O\&M costs in a gravity system would reduce to US $\$ 0.14$ per $\mathrm{m}^{3}$.

\section{Conclusions}

CF-UGF is a relatively new technology that has been applied in a few cases with rapid sand filtration. In this study CFUGF has been used in combination with MSF technology comprising UGF and SSF. This study shows that combining
CF-UGF with MSF greatly contributed to the removal efficiency of the system without negatively affecting the biological activity of the treatment system in terms of the efficiency of microorganism removal in the UGF and SSF when coagulant was dosed. This strongly contributes to the operational flexibility of the system as it allows to dose coagulant only when high influent turbidity peaks occur.

CF-UGF improved the operation of MSF compared to only UGF, when the system operated with turbidity levels above 30 NTU, facilitating the performance of the SSF by reducing the load of particulate material to avoid short filter runs and possible interruptions in treatment plant operation. The removal efficiency of turbidity in the CF-UGF with coagulant dosing was between 85 and $96 \%$, which is higher compared to operation without coagulant dosing; average efficiency of turbidity in the CF-UGF was $46 \%$, 
Table 9. Initial investment costs.

\begin{tabular}{lll}
\hline Stage of treatment & ${ }^{*}$ Cost (US \$) & $\%$ \\
\hline DRF & 9821 & 16 \\
CFUGF & 4554 & 7 \\
UGF & 17002 & 28 \\
SSF & 29783 & 49 \\
Total cost (US \$) & 61160 & \\
Cost l s ${ }^{-1}$ (US \$) & 10193 & \\
Per capita cost (US \$) & 18 & \\
\hline
\end{tabular}

${ }^{*}$ Costs up to February 2011.

ranging between $21-76 \%$. The addition of coagulant in the CF-UGF allowed for obtaining water with turbidity levels below 10 NTU after UGF, which contribute to the effective operation of the SSF. The overall system produced water with turbidity below 1 NTU for $98 \%$ of the samples that were taken in the research period. In the operation with coagulant the removal efficiency for total coliforms, E-coli and HPC, was $2.75,2.5$ and 2.6 higher respectively compared to the operation without coagulant in the CF-UGF and UGF units. No reduction was observed in the microbial removal efficiency of the SSF, no obstruction of the SSF beds were demonstrated and SSF runs were maintained between 50 and 70 days for a maximum head loss of $0.70 \mathrm{~m}$.

The hydraulic behaviour of CF-UGF indicated that the system worked with a plug flow fraction of $51 \%$, a mixed fraction of $46 \%$ and a dead zone fraction of $3 \%$. The comparison between the theoretical model and experimental data indicated that hydraulic behaviour of the reactor CF-UGF tends to $n=6$ reactors in series, confirming the presence of a relative plug flow. The mean residence time was $19.7 \mathrm{~min}$ for the operating flow of for the flow of $31 \mathrm{~s}^{-1}$; theoretical retention time was 19 min.

It was only necessary to operate the system with coagulant for $20 \%$ of the time. The CF-UGF run time was $6-100 \mathrm{~h}$ depending on raw water turbidity. In the operation without coagulant, the run time for the CF-UGF and UGF was 8 days. Whereas the designed drainage flow was established at $20 \mathrm{~m} \mathrm{~h}^{-1}$ in practice this level was not reached and the real flow according to the measurements in the units was about $9 \mathrm{~m} \mathrm{~h}^{-1}$ indicating that more research is needed on the effect of the drainage system during the cleaning operation.

The CF-UGF unit represented only $7 \%$ of the total construction costs, and the pre-treatment CF-UGF and UGF represented $35 \%$ of total costs, while the cost of $\mathrm{m}^{3}$ produced by the MSF with the CF-UGF system was US $\$ 0.05$, for a per capita investment of US\$18. The O\&M costs for the use of coagulant represented only $0.3 \%$ of the total O\&M costs. The production cost was US $\$ 0.264 \mathrm{~m}^{-3}$ for the operation with pumping. In a gravity system the cost is reduced to US $\$ 0.14$ per $\mathrm{m}^{3}$.
Table 10. Operation and maintenance costs.

\begin{tabular}{lll}
\hline Item & $\begin{array}{l}\text { Monthly cost } \\
(\mathrm{US} \$)^{*}\end{array}$ & $\%$ \\
\hline $\begin{array}{l}\text { Cost of coagulant (aluminium sulphate) } \\
\text { Cost of the chlorine }\end{array}$ & 13 & 0.3 \\
Staff costs (including benefits & 365 & 9.5 \\
and social security) & 1399 & 36.4 \\
Electrical energy costs & 1661 & 43.3 \\
Costs of materials and equipment & 249 & 6.5 \\
Costs for water quality analysis & 155 & 4 \\
Total monthly cost O\&M (US \$) & 3842 & \\
O\&M costs per $\mathrm{m}^{3}$ produced (US $\$ \mathrm{~m}^{-3}$ ) & 0.25 & \\
\hline
\end{tabular}

${ }^{*}$ Costs to December 2010

Acknowledgements. The authors acknowledge the support and trust received from the community and the governing board of Arroyo Hondo for the construction and evaluation of the system. They are also grateful for the fieldwork done by Carlos Mejia (FHIS, IRC-YZ program) and Diana Posso (Sanitary Engineer program, Univalle) and the plant operators Alfonso Escandón and Eulogio Mósquera. Financial and staff support for the study were received from the water supply research group of the Cinara Institute, Universidad del Valle, which included the use of the research station in Puerto Mallarino.

Edited by: A. Verliefde

\section{References}

Ahsan, T.: Process Analysis and Optimization of Direct Horizontal - Flow Roughing Filtration, Ph.D. thesis, Delft University of Technology, A.A. Balkema De, Rotterdam, The Netherlands, 193 pp., 1995.

APHA, AWWA, and WPCF: Standard Methods for the examination of water and wastewater, USA, 21a Edn., 2005.

Attakoya, A., Prasad, V. S., and Nagaraja, S. V.: Performance study of granulated flocculators, Indian Jour. Evir. HLTH., 33, 498504, 1991.

Bates, B. C., Kundzewicz, Z. W., Wu, S., and Palutikof, J. P. (Eds.): El Cambio Climático y el Agua. Documento técnico del Grupo Intergubernamental de Expertos sobre el Cambio Climático, Secretaría del IPCC, Geneva, 224 pp., 2008.

Bhole, A. G.: Design and fabrication of a low cost water treatment plant for rural areas in India, Aqua, 5, 315-320, 1981.

Burganos, V. N., Paraskeva, C. A., Christofides, P. D., and Payatakes, A. C.: Motion and deposition of non-Brownian particles in upflow collectors, Sep. Technol., 4, 47-54, 1994.

Centro Panamericano de Ingeniería Sanitaria y Ambiental (CEPIS): Tratamiento de agua para consumo humano, Filtración Rápida, Perú, 2004.

Cinara: Estudio de tratabilidad planta de potabilización de la parcelación Colinas de Arroyohondo; proyecto: ASOPROCOLAR , Cali, Colombia, 27 pp., 2004.

Cinara and International Development Research Centre (IDRC): Proyecto limpieza hidráulica de filtros gruesos, Final report, Cali, Colombia, 110 pp., 1993. 
Cinara and IRC: Potencial de la filtración gruesa en múltiples etapas (FiGME) en la optimización de plantas de tratamiento con filtración rápida de agua químicamente coagulada, Cali, Colombia, 1996.

CGR - Contraloría General de la República: Estado de los Recursos Naturales y del Ambiente, República de Colombia, 180 pp., 2009.

Cleasby, J. L.: Source Water Quality and pretreatment option for slow sand filters, Chapter 3, in: Task committee on slow sand filters, New York, USA, 1991.

Di Bernardo, L. and Cruz, C. H.: Influencia de altas tasas de filtración en el desempeño de sistemas de filtración directa ascendente, in: proceeding of XXIV Interamerican Congress of Ingeniería Sanitaria y Ambiental, Buenos Aires, Argentina, 1994.

Di Bernardo, L. and Sabogal, L. P.: Seleção de tecnologias de tratamento de água, Editora LDIBE LTDA, Sao Carlos Brasil, I, 878 pp., 2009.

Dinoy, A. A.: Friction Factor and Reynolds Number Relationship in Flow through Porous Media, ME thesis, AIT, Bangkok, Thailand, 1971.

Dorea, C. C. and Clarke, B. A.: Impact of chemical pretreatment in Slow Sand Filtration, in: proceeding of Recent progress in slow sand and alternative biofiltration processes, IWA publishing, 215-223, 2006.

Ergun, S.: Fluid Flow Through Packed, Colum. Chem. Eng. Prog., 48, 89-94, 1952.

Fair, G. M., Geyer, J. C., and Okun, D. A.: Purificación de aguas y tratamiento y remoción de aguas residuales, Fifth reprint, Editorial Limusa Mexico, II, 764 pp., 1984.

Galvis, G.: Development and evaluation of multistage filtration plants; an innovative, robust and efficient water treatment technology. Ph.D. thesis, Guilford, UK, CEHE, University of Surrey, 228 pp., 1999.

Galvis, G., Latorre, J., and Visscher, J. T.: Filtración en múltiples etapas, tecnología innovative para el tratamiento de agua, Universidad del Valle, Instituto Cinara, Cali, Colombia, International water and sanitation centre, IRC, The Netherlands, UNESCO, united nations office for science and culture, 197 pp., 1999.

Ives, K. J.: Testing of filter media, J. Water SRT Aqua, 39, 144-151, 1990.

Kardile, J. L.: Development of simple and economic filtration methods for rural water supplies, Aqua-Fenicca, 1, 226-229, 1981.

Kawamura, S.: Two stage filtration, J. AWWA, 77, 42-47, 1985.

Lloyd, B. and Helmer, R.: Vigilancia y control de la calidad del agua para consumo humano en la zona rural, Published for the WHO and UNEP by Logman Scientific and Technical, 1991.
Ministerio de Desarrollo: Inventario nacional del sector de agua potable y saneamiento básico, Vol. I Infraestructura física de los sistemas. Ministerio de Desarrollo Económico, Viceministerio de Desarrollo Urbano, Dirección de servicios públicos domiciliarios, Colombia, 13-67, 1998.

Pérez, J. and Galvis, G.: Análisis de flujos y factores que determinan los periodos de retención, Centro de Ingeniería Sanitaria y Ciencias del Ambiente, CEPIS, Organización Panamericana de la Salud, OPS, II, 112 pp., 1990.

Richter, C.: Sistemas simplificados de floculación, in proceeding of Seminario Internacional sobre Tecnología Apropiada para Potabilización del Agua, ACODAL, seccional Valle del Cauca, Cali, Colombia, August, 1987.

Richter, C. A. and Moreira, B. R.: Floculadores de Pedras. Experiencia en Filtro Piloto, Reporte interno Sanepar, Parana, Brasil, 1981.

Rocha, M. A., Normando, H., and Onofre, C.: Aplição de tracadores em filtros anaeróbicos para avaliação das características hidrodinámicas, in: Proceeding of XXVII Congresso Interamericano de EngenhariaSanitária e Ambiental, Porto Alegre, Brasil. Associação Brasileira de Engenharia Sanitária e Ambiental Região Rio Grande do Sul (ABES/RS), 2000.

Salazar, M. and Ocampo, J.: Estudio sobre la eficiencia hidráulica y remoción de material suspendido en clarificadores ascendentes de gravas estratificadas, Universidad del Valle, Cali, Colombia, 1999.

Sánchez, L. D., Burbano, L. M., and Sánchez, A.: Multi stage filtration to prevent biofilm growth in a distribution network, in: proceeding of recent progress in slow sand and alternative biofiltration processes, IWA publishing, 511-518, 2006a.

Sánchez, L. D., Sánchez, A., Galvis, G., and Latorre, J.: Multi-Stage Filtration, Thematic overview paper 15, IRC International Water and Sanitation Centre, 64 pp., $2006 \mathrm{~b}$

Santamaría, J.: Comparación de la floculación mecánica y la floculación en clarificadores ascendentes en gravas estratificadas, Universidad del Valle, Cali Colombia, 97 pp., 1999.

Schulz, C. R. and Okun, D. A.: Surface water treatment for communities in developing countries, John Wiley \& Sons, New York, 299 pp., 1984.

WHO: Guidelines for Drinking Water Quality. World Health Organization, Ed. WHO library, 4th Edn., 564 pp., 2011.

Wolters, H.: Roughing Filtration a Literature Study, MSc thesis Report, TU Delft, 173 pp., 1988.

Wright, D. E.: Non-linear flow through granular media, Proceeding American Society Civil Engineering, Journal Hydraulic, 94, 851-872, 1968. 